\title{
The Ukrainian conflict in Russian foreign policy: Rethinking the interconnections between domestic and foreign policy strategies
}

\section{Licínia Simão}

School of Economics and Centre for Social Studies, University of Coimbra, Coimbra, Portugal

\begin{abstract}
This article analyses Russia's role in the Ukrainian crisis in the context of Moscow's foreign policy historical development, underlining patterns of continuity and change in its policies towards the CIS. It argues that Russian foreign policy towards Ukraine results from a combination of two trends, reinforcing a Russian interventionist agenda: perceived threats to Russia's interests in the near abroad and a radicalised and conservative national spectrum shaping foreign policy decisions. The combination of domestic and external factors driving Russia's agenda in the near abroad raises important challenges for Russian society and its leaders as it does for its neighbours and partners.
\end{abstract}

ARTICLE HISTORY Received 19 November 2014; Accepted 31 August 2015

KEYWORDS Foreign policy; national identity; secessionist conflicts; Ukraine; Russia

\section{Introduction}

Russia's role in the insurgent wars ongoing in the post-Soviet space remains a central element in understanding their development, maintenance, and central features. Simultaneously, these conflicts also play a role in Russia's domestic and international politics. The most recent illustration of Russia's instrumental role in supporting separatist conflicts in the post-Soviet context is the ravaging war in Ukraine, since March 2014. This article places the current Ukrainian conflict within the context of the development of Russian foreign policy more generally. The main argument is that Russian foreign policy towards Ukraine results from a combination of two trends, reinforcing a Russian interventionist agenda: perceived threats to Russia's interests in the near abroad and a radicalised and conservative national spectrum shaping foreign policy decisions. 
Managed instability has become a goal in itself for Russian foreign policy, and the consequences of this strategy both domestically and abroad can only be endured by relying on a radicalisation of the national spectrum, which poses important risks for Russia and its neighbours.

Russia's foreign policy in the post-Cold War context has evidenced two parallel dynamics: firstly, a re-centralisation of decision-making in the Kremlin accompanied by a conservative turn regarding Russia's historical identity and modern role, especially visible since Vladimir Putin's rise to power; secondly, the renewed importance of the international context and Russia's perceived relative power within this system. Centralisation was needed to re-establish order in the Russian political and bureaucratic system, following the chaotic transition from the Soviet period in the Yeltsin years, ${ }^{1}$ establishing the new president as a strong national and international leader. ${ }^{2}$ This also contributed to improve Russia's self-image in the post-Soviet context. It is therefore no surprise that many analysts have underscored the interplay of domestic and international concerns underlying Russia's position towards Ukraine, since the country began edging towards the European Union (EU) and the North Atlantic Treaty Organisation (NATO). ${ }^{3}$ What has consistently been perceived by part of the Russian elite as a strategy of encirclement by the United States and NATO is now actively and successfully being undermined by sustaining managed instability in Ukraine and playing on the West's anxieties regarding the poor democratic and economic credentials of many of the post-Soviet countries looking to join the EU and NATO. Thus, it can be argued that this strategy serves both the goal of protecting the nature of the regime at home and Russia's perceived foreign policy and geopolitical interests in its 'near abroad'.

This has translated into a simultaneously reactive and proactive foreign policy, through which Russian leaders seek to influence dynamics in the international system, often responding to perceived threats and opportunities. This trend, culminating in the Ukrainian crisis, has been clear for some time; indeed, resort to insurgent and proxy wars has been part of the portfolio of instruments used to advance the Kremlin's foreign policy interests since the fall of the Soviet Union. Russian official documents have established Moscow's right of intervention in the post-Soviet space in order to defend ethnic Russians abroad $^{4}$ and established the Commonwealth of Independent States (CIS) as an area of privileged interests for Russia. ${ }^{5}$ The Russian Federation's intervention in the secessionist conflicts in the South Caucasus and Moldova, during the 1990s, has been well documented, ${ }^{6}$ but it is the contention of this article that these conflicts have regained strategic relevance for Moscow since the arrival to power of President Putin, and especially since his re-election as president of the Russian Federation in 2012. They provide important leverage in Russia's strategy of limiting the advancement of pro-Western ideas in the CIS, while being a central part of a new narrative of Russian identity, linked to the 'role of 
the historical motherland' in these regions and a new-found mission of uniting and reviving the 'Russian world'?

Thus, although it is clear that the CIS remained a central area for Russia's foreign policy, deserving a more proactive approach on the part of the Kremlin, its policies have nevertheless remained bound by the need to react to the perceived aggressive posturing by the United States and European powers towards the region. The tilting point of these reactive policies was triggered by the colour revolutions in Georgia, in 2003, and later by events in Ukraine in 2004. In Georgia, Russia's influence proved limited, whereas in the case of Ukraine, Moscow could rely on an important Russian economic and financial presence in the country and on internal divisions among Ukrainians regarding their strategic alignment, as a strategy of long-term undermining of the country's pro-Western ambitions.

During the current crisis, Russia's strategy towards Ukraine has been informed by the twin dynamics bearing on Russian identity: perceived pressures at the regional and international level, resulting in a strategy of containment of Russian interests in the near abroad; and an increased radicalisation of the national spectrum, placing Russian domestic politics on a conservative and messianic note, which reinforces an interventionist agenda. This article analyses the interactions between the domestic and the international levels, in order to understand Russia's central role in Ukraine, in the context of its foreign policy development. Due to the mutual influence of domestic debates on Russian identity and its regional and global standing, Russian support for insurgency and use of military pressure on the CIS countries is infused with a narrative of normative obligations towards Russian compatriots and operationalised by policies of military renovation aimed at reviving a vision of Russia as a great power. This combination has made Russian foreign policy and its engagement in the secessionist conflicts more erratic and less driven by rational interests and therefore less predictable.

\section{The domestic and external in Russian foreign policy: The challenge of identity-building}

Russian foreign policy in the post-Soviet context has had to address, first and foremost, the challenges of transition. Because the Soviet Union was one of the superpowers structuring the Cold War order, its collapse implied radical changes at the global, regional, and domestic level for Russians and their leaders. This heritage as a former superpower remained one of the central elements in post-Soviet Russian foreign policy, as the search for a new identity was established as a main priority by the Yeltsin Administration and a central challenge to President Putin. Russia's international identity as a great power was formally assured by keeping the Soviet Union's seat in the United Nations Security Council (UNSC), but the internal and regional dilemmas about national identity proved more complex. As Lo argues, '[i]t was one thing to inherit the legal status and even bulk 
of the defunct empire's assets and responsibilities, but it was quite a different challenge to find answers to difficult questions about Russia's nature and role in the post-Cold War environment.' 8 Sakwa goes further in the argument about the complex process of forging a nation out of post-Soviet Russia, stating that ' $[\mathrm{n}]$ ational identity is about definite and defensible space; it is also about imbuing that space with a sense of common purpose and destiny' ${ }^{9}$

The search for a post-Soviet identity in Russia remains an open process making Russia a unique case among great powers. This process further reinforces the dynamic interaction between the domestic and international levels, as Russian national identity remains closely linked to its international standing and vice versa. As Freire argues, 'the post-Soviet identity construction accompanies the redefinition of Russian policies under Vladimir Putin, suggesting a "new" Russia, built on the foundations of the "old" empire'.10 This has meant that Russia's relations with the CIS remain a fundamental part of its identity-building process, seeing it as an area of strategic importance for Russia's security and its international standing. In all official and strategic documents, the CIS is identified as Russia's sphere of influence and a region where Moscow holds privileged interests. EU and NATO interference in the former USSR has been a major point of contention in Russia's relations with its Western partners. ${ }^{11}$ Furthermore, the issue of the Russian minorities in the former USSR republics has been a divisive issue in Russian domestic politics, with important implications for its foreign policy towards the region. ${ }^{12}$ Thus, one cannot dissociate one aspect from the other, when trying to understand Russian foreign and security policy towards the CIS countries.

These views on national identity are central to our understanding of the role Russian foreign policy has in domestic and regional politics, especially as regards Moscow's active military and political engagement in the secessionist conflicts in the former USSR throughout the 1990s but also, and perhaps more clearly, since the 2000s. Under President Putin, Russia's war in Chechnya and its active engagement in Abkhazia and South Ossetia, as well as Transnistria and Nagorno-Karabakh have been explained by a need to assure the cohesiveness of the Russian state and its protection from centrifugal forces advancing in its direction. In President Putin's own words,

[t] he essence of the situation in the Caucasus and Chechnya was a continuation of the collapse of the USSR. It was clear that we had to put an end to it at some point ... My evaluation of the situation in August [1999] was that if we don't stop it immediately, Russia as a state in its current form would no longer exist. ${ }^{13}$

Despite the contradictions inherent in Russia's view of territorial integrity and humanitarian intervention, ${ }^{14}$ as exposed in its interventions in Georgia, in 2008 and in Ukraine, in 2014, the main logic driving Russian foreign policy has been what Trenin has called the objective of 'winning full sovereignty for Russia', ${ }^{\prime 5}$ meaning that foreign policy should contribute to domestic consolidation around a nationalist ideal and freedom of action in the so-called 'Russian 
world', to promote Russian interests. In this sense, the geopolitical borders of Russia do not coincide with its political ones, since the protection of the Russian state requires an active engagement in its near abroad as a means of assuring political and military influence. Furthermore, the use of the humanitarian argument is meant not to reinforce it, but rather to unmask the power politics and hypocrisy underneath the West's use of the principle. In doing so, however, Russia unmasks its own hypocritical stance.

Russia's anchoring to the CIS and the fundamental importance of this area for the definition of its national identity and geopolitical borders carries important consequences for Russia's international standing. On the one hand, it limits Moscow's ability to pursue more ambitious foreign policy strategies elsewhere, namely in its relations with Western countries and in global governance structures. On the other hand, as strategic competition with the West grows in the CIS region, Russia has recurrently pulled back into logics of military spending, diverting important funds from its modernisation strategy. ${ }^{16}$ As the Ukrainian conflict illustrates, this means increased marginalisation of Russia from the dominant Western world order (limiting its participation in the G8, suspending cooperation with NATO, and limiting contacts with the EU, for instance) and a redefinition of Russia's international status as a pariah state.

\section{From economic leverage to military force: Shifts in Russian foreign policy towards the CIS}

As argued above, Russian foreign policy towards the CIS suffered initially from a lack of strategic direction and capacity. Internal debates in Russia over the role and importance of the former Soviet countries evidenced strong divisions between those who perceived this area as having strategic importance for Russia's own security and global status, and those who perceived it as a burden weighing on Russia's already fragile economy and institutional structures. Regardless, Russia's presence and influence was assured by the establishment of the CIS, in 1992, whereas the Russian army remained engaged in the violent conflicts erupting on the southern borders of Russia, namely in Georgia, Moldova, and Azerbaijan. Russia came to dominate the mediation formats for these conflicts, and the peacekeeping forces deployed on the ground legitimised its military presence in the former Soviet republics. For most of the 1990s, this military presence was underutilised to derive political benefits for Russian foreign policy, partly due to the more urgent concern with the deterioration of the security situation in the Russian North Caucasus. The wars in former Yugoslavia and Western intervention, namely in Kosovo, added further pressure on Russia to redefine its international standing, and that required, among other things, a redefinition of its CIS policies.

President Putin's arrival in the Kremlin inaugurated a new style of politics in Russian foreign policy and a new strategic vision regarding the re-establishment 
of Russia's great power status. The first step was to reorganise power structures domestically and initiate a centralisation of power around the president. This would allow for better management of the bureaucracies and pressure groups, and thus assure better control over policy-making. ${ }^{17}$ The second step was to reposition the Russian economy in the global scene, using energy resources as a central means of power projection. ${ }^{18}$ As the energy infrastructures feeding Russia's production linked it to the Caspian and Central Asian regions, this provided Russia simultaneously with a challenge and an opportunity regarding relations with CIS governments. This also made relations with the EU particularly important, being Russia's main and most attractive energy market, and raised new issues regarding Russia's relations with Ukraine and Belarus, as two vital transit countries. The third element repositioning Russia in the regional and global context was the revitalisation of its military power and the use of performative politics ${ }^{19}$ and unrestricted warfare tactics. ${ }^{20}$ Thus, the combination of domestic and external dynamics, as well as economic and military means became more streamlined and integrated under President Putin. Military intervention in Georgia in 2008 and Ukraine in 2014 should thus not be seen as a novelty and a radical shift in Russian foreign policy, but rather as a more muscular take on the use of military means for the attainment of foreign policy goals, as well as a display of opportunistic interventions with clear counter-revolutionary goals. ${ }^{21}$ These views are fundamental in the analysis of Russia's foreign policy in the case of Ukraine.

The focus on energy as a central element in the revitalisation of Russia's global standing was accompanied by other initiatives on the economic front. In fact, within the CIS, as early as 1994, a free trade agreement was signed by all member states, but it was only during President Putin's presidency that a reinvigorated economic agenda began to develop. The goal was to establish a common economic space, but this goal faced important hurdles, due to the unbalanced nature of economic relations between Russia and other CIS countries, as well as the generalised fear that Russia would use economic integration mechanisms as a means of political leverage and interference. Thus, in 2000 only five of the CIS states agreed to the establishment of the Eurasian Economic Community (EurAsEc) - Russia, Belarus, Kazakhstan, Tajikistan, and Kyrgyzstan - and it was only in 2012 that a Customs Union was finally agreed, which was limited to Russia, Belarus, and Kazakhstan. ${ }^{22}$ This vision of economic integration was topped by President Putin's announced Eurasian Union, which should also encompass an important political dimension. ${ }^{23}$

The view behind this Russian-led economic integration was summarised by Anatoly Chubais, in October 2003, when he 'suggested the transformation of Russia into a liberal empire that would dominate economically and culturally the former Soviet space. ${ }^{24}$ This view was inspired by US actions in the context of the global war on terror, promoting a political and economic liberal empire, backed by military force. ${ }^{25}$ Western-backed revolutions in Georgia (2003) and in Ukraine 
(2004) furthered the view that Russia should develop a counter-strategy, infusing this 'liberal empire' notion with cultural aspects, alongside economic ones. The view that Russia has strategic economic interests in its near abroad, which include control of attractive economic assets, particularly energy-related ones, sustained a series of aggressive moves to assert control in countries like Belarus, Ukraine, and Armenia. Russian companies acquired important shares of these countries' energy infrastructures (or sought to do so) in exchange for loans or energy price reductions, and military assistance in the case of Armenia. This naturally translated into an increased degree of political control over local regimes, facilitating Russia's goal of establishing friendly and subservient governments within its near abroad. The case of Ukraine, as we will see later, however, was not linear, adding tension to already difficult bilateral relations.

The transition towards more muscular means of pressure, including military intervention in Georgia and Ukraine raises questions regarding Russia's role in restructuring the European security order, but also requires further analysis as to why such moves took place in Russian foreign policy-making. What role has military force played in Russian perceptions of its post-Soviet regional and global position? What were the expected results of such actions? What has been achieved so far? As mentioned above, Russia's role in the management of the violent conflicts which erupted along its southern border, in the Caucasus and Moldova, set the stage for a long-term military presence in these countries. Currently, Armenia and the breakaway regions of Transnistria (Moldova), Abkhazia and South Ossetia (Georgia) harbour Russian military bases. Azerbaijan has avoided the presence of Russian military facilities since independence, whereas Georgian controled territories do not host Russian military bases, since $2007 .{ }^{26}$ Despite this presence, up until 2008, Russia refrained from direct military intervention or covert military action in Moldova, Georgia, Armenia, and Azerbaijan, in order to influence the pace of events. Russia even endured and complied with Georgia's decision to terminate Russia's military presence in the country. Both sides reached agreement in 2005 on a timeline for Russia to hand over these facilities to Georgian authorities. The last base, in Batumi, was closed in 2007.

Despite this restraint and these setbacks, it gradually became apparent that the military remained an essential part of Russia's self-perception of greatness. The Kremlin has systematically invested important amounts of its annual budget in the modernisation of its military. ${ }^{27}$ It also engaged in military exercises in the Caspian and Central Asia in 2002 and 2005, and threatened to intervene against Chechen fighters' refuges in Georgia's Pankisi Gorge, also in 2002. Looking to counteract the US presence in Central Asia after 9/11, Russia opened a military base in Kyrgyzstan in 2003. Frustrated with the lack of ratification of the Conventional Armed Forces in Europe Treaty by new NATO members in Central and eastern Europe, Russia withdrew from the treaty in 2007. Finally, leading up to the war with Georgia, in the summer of 2008, Russia engaged in several 
incursions into Georgian territory, escalating tensions. Thus, Russia's use of the military instrument in its foreign policy has been erratic and, as argued by Pavel Baev, '[the] conceptualization of these interventions remained quite underdeveloped with a particular mix of residual desires for imperial revanche, vague feelings of post-imperial responsibility, and imported ideas about "muscular" peace-keeping.'28

The decision to intervene militarily in Georgia in 2008 and in Ukraine in 2014 (although Russia's official position is that no Russian troops are or were utilised in the conflict) represents a qualitative shift in Russia's strategy towards the CIS countries. In its attempt to use regional influence as a springboard for global recognition, Russia had refrained from direct military intervention, not only due to concerns regarding its image as a responsible power in world affairs and a defender of international legality (from its permanent seat in the UN Security Council, to its denunciation of US global interventionism), but also due to concerns that such actions would backfire and raise fears of imperial domination in the former USSR. The interventions of 2008 and 2014 question both goals and have resulted in a more fragile position for Russia both globally and regionally. Although Russian leaders including presidents Medvedev and Putin as well as Foreign Minister Lavrov have tried to articulate a legitimation of Russia's interventions, this has been achieved mainly through what Dunn and Bobick call a satire of humanitarian arguments. ${ }^{29}$ As the authors argue, '[i]n declaring that its attempts to reestablish the Soviet empire are merely an exercise of the Responsibility to Protect [. . .] Putin performs the same script as Western advocates of R2P [. . .] overtly claiming to use the same principle of humanitarian action that the West does while transparently revealing an equivalence between U.S. and Russian imperial ambitions.'

Whether we can speak of Russian imperial ambitions, or whether Russian foreign policy towards the CIS is just a display of great power ambition and security concerns, is less relevant for our argument. What is central to understand in Russia's strategy towards Ukraine and the role of this conflict in Russian foreign policy is rather the ability to place these decisions and actions in a continuum of foreign policy, within which the use of the military instrument has been recurrently on the table. Military interventions in the secessionist conflicts in Georgia, Azerbaijan, and Moldova in the 1990s have been carefully legitimised through international mandates and bilateral agreements. They have also been restrained to the separatist territories, allowing for the explicit defence of the principles of national sovereignty, territorial integrity, and self-determination. Despite the obvious limitations and contradictions imbued in these principles, and Russia's non-military interference in the domestic affairs of these countries, the intervention in Georgia in 2008 and in Crimea in 2014 are simultaneously a continuation of a reactive foreign policy and a clear display of opportunistic decision-making. The outcome, however, poses important challenges to Russia's international, regional, and domestic standing, as Russia has been perceived 
as an aggressive state, a regional destabiliser, and an irresponsible partner in international security management. In the following section, we set the background of Ukrainian-Russian relations vis-à-vis possibilities of intervention and destabilisation, in order to establish the precedents of the latest crisis.

\section{From lack of strategy to limited intervention: Russia-Ukraine relations after independence}

Relations between post-Soviet Russia and Ukraine have evidenced a striking paradox. On the one hand, the importance of Ukraine for Russia is widely established and agreed; on the other hand, there has not been a consistent and coherent strategy towards the country over the last 20 years. ${ }^{30}$ Despite the significant steps taken under President Putin's leadership to improve Russia's attention and influence in Ukraine, the fast speed of events unfolding since 2004 has once more dictated a reactive Russian foreign policy towards Kiev. This was visible both in the management of the Orange Revolution in 2004 and in Russia's response to the Maidan protests of 2013.

As the focus of our analysis is placed on the role of military force and especially separatist conflicts in advancing Russian foreign policy goals in the CIS, the case of Ukraine appears as a particularly important illustration of this trend. Though Crimea and the presence of the Black Sea Fleet in Sevastopol have been important, if contentious, issues in bilateral Russia-Ukraine relations, it is striking that the current crisis, unlike previous ones, has escalated to full annexation of Crimea into the Russian Federation and that an ongoing violent conflict is being sustained in eastern Ukraine. In this section, we thus look at the evolving roles of Crimean separatism and the Black Sea Fleet in Russian-Ukrainian relations since 1991, and we link this to the interplay of domestic and external dynamics set in motion during this crisis and which shape the outcomes of Russian foreign policy.

The status of Crimea within independent Ukraine has been an issue of contention since the break-up of the Soviet Union. Until then, Khrushchev's decision to transfer the administration of the peninsula to Ukrainian control in 1954 remained a mainly symbolic gesture with few practical implications for everyday life within the USSR. With Ukraine's independence, the status of the peninsula and of the Black Sea Fleet had to be regulated through bilateral agreements between Russia and Ukraine. The application of the principle of uti possidetis meant that Crimea would automatically be a part of sovereign Ukraine, but the nationalities policies of the Soviet Union created a matrioska-like structure of territorial governance allowing for important levels of autonomy to be pursued under independence. Thus, as early as 1991, Crimea held a referendum on whether it should become a Republic of the Soviet Union, rather than an oblast of the Ukrainian Soviet Republic. This translated into reinforced autonomy for Crimea within the Ukrainian SSR - a status which would be reinforced 
in subsequent years following independence. Between late 1991 and 1994, juridical relations between independent Ukraine and Crimea were restructured, with important levels of autonomy being granted to the region. In 1994, local elections reinforced the control of the 'Russian Bloc' party, which advanced a clear separatist agenda, raising tensions in relations with Kiev and opening the possibility for Russian interference in Ukrainian affairs.

Considering Russia's practices elsewhere in the former USSR during the 1989-1994 period, namely its support for the separatist movements in Abkhazia and South Ossetia, as well as for the Armenian forces fighting Azerbaijan over Nagorno-Karabakh, Russia's restraint in Crimea is noteworthy. ${ }^{31}$ This is especially so considering that the Black Sea Fleet was stationed in Sevastopol and that an agreement on the division of the fleet was not reached until 1997, encompassing the division of the fleet's assets, stationing rights, and control over Crimea. Arguably, the strategic value of the fleet itself was less linked to the ability of its vessels to patrol the Black Sea and monitor the Mediterranean, since these had been ageing for years without major investments, but rather the ability to provide Russia with the means and justification to exert pressure on Ukraine and maintain a symbolic presence in the peninsula. ${ }^{32}$ In fact, the fleet and the Russian ethnic community in Crimea have regularly been used as instruments of pressure towards Ukraine since independence, despite of (or perhaps because of) the lack of a strategy shaping bilateral relations.

Three main tools of pressure are worth recalling, as they remain relevant to understanding Russian actions in the 2013 crisis. The first is the use of the Black Sea Fleet and its military staff and local status to expand Russian de facto imposed limitations of Ukrainian sovereignty over Sevastopol and Crimea. The 1997 agreements already established important opportunities for Russian interference in Ukraine, namely by inscribing in the Ukrainian constitution the possibility of leasing its military facilities to external actors. Together with Russian reluctance to accept and recognise Ukraine's independence, sovereignty, and territorial integrity, these issues compound an important means of pressure on Kiev. This was echoed in nationalist statements coming from the Duma or the outspoken Moscow mayor Yuri Luzhkov, stating that Sevastopol was and would always be a Russian city. But it was under the 2010 agreement on the extension of the leasing of the Sevastopol port to harbour the Black Sea Fleet that Russia's use of the base as a means of limiting Ukraine's sovereignty over Crimea became more apparent. One aspect included in the agreement reached between Presidents Medvedev and Yanukovych was the increase in non-military Russian staff, which implied the return of the Federal Security Service (FSB) to Crimea (their presence had been terminated in 2009 under President Yushchenko). ${ }^{33}$ Moreover, Russian leaders, including President Medvedev also denounced the 2008 Ukrainian decision to start preparing for an early departure of the Black Sea Fleet from Sevastopol. Russia also clearly articulated the idea that Ukraine's sovereign decision to seek NATO membership would pose a 
threat to Russian security, ${ }^{34}$ and that its attempts to disconnect Russia and the Fleet from Sevastopol posed not only a strategic threat but also an historical one. ${ }^{35}$ Thus, either directly or rhetorically, the Black Sea Fleet facilitated Russia's interference in Ukrainian politics and de facto challenged its sovereign control over Crimea.

The second aspect used to exert pressure on Ukraine has been the presence of ethnic Russians in Crimea and Russia's historical connections to the region. Russia's official documents have explicitly made the protection of Russian's living abroad - Russian citizens and compatriots - a central task of its foreign and security policies. Since the adoption of the Foreign Policy Concept and the Russian Military Doctrine of 1993, ${ }^{36}$ this has become a potential source of tension in Russia's relations with CIS countries, especially those hosting large ethnic Russian groups such as Ukraine, Belarus, and Kazakhstan. Reinforcing the outreach of this policy, Moscow has also engaged in an active policy of attributing Russian passports to citizens of other CIS countries, namely those living in non-recognised de facto states such as Abkhazia, South Ossetia, and Transnistria. ${ }^{37}$ It has been argued elsewhere that that such a passportisation policy'is not merely a neutral response to the patriotic demands of the pro-Russian element[s]. Accepting a Russian passport signifies legal inclusion in the Russian body politic, with everything that that connotes. Distributing Russian passports on the territory of another sovereign state is therefore loaded with political, territorial, and legal significance, which the case of Georgia amply demonstrates.'38 This process creates a context of overlapping sovereignty over an important part of the political body of the state - its population and the territory they live in.

Nevertheless, although by the early 2000s, Russia was actively pursuing this policy in the separatist regions of Georgia, it did not engage in an active policy of passportisation in Crimea and eastern Ukraine prior to the crisis in 2013. This is partly due to the fact that both Crimea and eastern Ukraine are ethnically heterogeneous places, with strong ties to the Ukrainian central state, which have reinforced Ukrainian sovereignty and created divisions over whether there are clear advantages in seeking to join Russia. This is reinforced by the Ukrainian law forbidding dual citizenship and active measures taken by President Yushchenko, especially after the Georgian-Russian war of August 2008, denouncing such attempts in Crimea. ${ }^{39}$ Besides the Kremlin, the nationalist card has also been played by leading figures in the Russian political spectrum. Konstantin Zatulin, the leader of the Committee on CIS matters in the Russian Duma has been an active supporter of pro-Russian movements and parties in Crimea and an advocate of Russian control over the peninsula and, particularly of the city of Sevastopol. Under his leadership, the Duma has been outspoken whenever the Russian government was perceived as recognising Ukrainian sovereignty over Crimea (namely during negotiations of the 1997 Russian-Ukrainian Friendship and Cooperation Treaty and during negotiations for the renewal of the Black Sea Fleet leasing, in 2010), or even when the Ukrainian government adopted 
measures which were perceived as limiting the rights of local ethnic Russians. ${ }^{40}$ Zatulin sought to shape the Russian agenda towards Ukraine, supporting a view of a non-allied Ukraine, integrated into a common economic space with Russia, eventually federalised, and having Russian constitutionally recognised as a second language. ${ }^{41}$ Similarly, the Moscow mayor - and one time presidential hopeful - Yurii Luzhkov has, since the mid-1990s, been an active supporter of nationalist issues, and Crimea has been a flagship issue in his political activities. ${ }^{42}$ Both Luzhkov and Zatulin have acted as policy entrepreneurs, providing support for local pro-Russian initiatives and keeping the nationalist issue of the ethnic Russians in Crimea on the Russian government agenda.

The third tool of Russian pressure on Ukraine has been economic. Since the establishment of the CIS, Russia has advanced economic integration as a central part of its political vision for the area. Ukraine integrated into the CIS Economic Union but only as an associate member, disputing Russia's view of a deeper form of regional economic integration and requesting instead a free trade agreement. The establishment of the Eurasian Economic Community, in 1996, once more evidenced tensions at the trade and economic level between Moscow and Kiev, and the negotiation of the Common Economic Space once more failed to fully include Ukraine, which preferred an observer status. This resulted in several trade wars between the two countries as a means to applying pressure and punishing, but which have overall failed to push Ukraine into the Russian economic sphere of influence. ${ }^{43}$ Ukraine's financial problems have also made it particularly vulnerable to Russian financial support in exchange for strategic assets, namely the leasing of the port of Sevastopol for the Black Sea Fleet or subsidising of energy in exchange for the use of the pipeline system linking Russia's energy production to the EU markets. ${ }^{44}$ Due to the many problems in Ukrainian domestic economic management and policy, Russia's ability to influence politics in the country by resorting to economic means has been a constant, but it has also been a need, considering the extensive interdependence between the two countries' economies.

Considering these tools and approaches, we look now at how these have been activated during the latest crisis of 2013. We are particularly interested in mapping the shifts in the Russian understanding of the role of the military instrument in its foreign policy strategy, as well as the interplay between internal and external dimensions in Russian foreign policy towards Ukraine.

\section{Instability in Ukraine and Russian foreign policy}

The escalation of the conflict opposing the Ukrainian and Russian governments in 2013 exhibits many of the trends identified in previous moments of their bilateral relations since independence. Economic and financial pressure were central tools in Russia's engagement with Ukraine in the lead-up to the 2013 crisis, the presence of ethnic Russians in Crimea was the symbolic justification for support for their claims to independence and for annexation into the Russian 
Federation, while Russia's military presence in Crimea through the Black Sea Fleet also facilitated its control of the peninsula. Russia also resorted to an all-out media campaign of propaganda to counter Western narratives of the crisis and of the intervention itself, displaying new levels of sophistication on this front. Finally, Russian leaders have also made it clear that they are willing to gamble their political future on foreign policy issues. In order to understand and qualify this last point, it is necessary to recall that for many in Russia, Ukraine and Crimea in particular are not foreign issues, but rather an integral part of the Russian/ Slavic/Orthodox community and thus part of Russia's national revival. Thus, we are confronted with patterns of continuity and change in Russian foreign policy-making, suggesting new levels of sophistication on some fronts, a new perception of Russia's global standing and possibilities, as well as a new domestic context, where the centrality of the president is gradually being challenged by strong nationalist movements pushing for more radical action vis-à-vis the former Soviet space.

Preceding the military escalation of the conflict, Russian-Ukrainian relations need to be understood from the perspective of both countries' relations with the United States and the EU. As we have argued above, Russia's self-perceived image as a promoter of multipolarity and a direct challenger of Western attempts to expand into Eurasia resulted in increased tensions over the last two decades. NATO enlargement has been a central point of contention, and the argument has been made that Russia's decision to intervene in Georgia in 2008 was not only a reaction to President Saakashvili's military intervention in South Ossetia, but mainly an opportunity to reinforce Moscow's position in the two separatist regions as a means of hampering any future accession hopes for Georgia. Russian leaders openly acknowledged that NATO enlargement posed a threat and that they would be willing to do anything to prevent it. Although Ukraine, under the pro-Western leadership of Viktor Yushchenko displayed strong support for Georgia, namely seeking to limit the use of the Black Sea Fleet during the crisis, the election of the pro-Russian Viktor Yanukovych as president in 2010 meant that Russia had successfully avoided NATO enlargement both to Georgia and Ukraine without major external or domestic costs.

However, in the run up to the 2013 crisis, it became apparent that President Yanukovych would look to capitalise on both European and Russian interest in Ukraine in order to keep the fragile Ukrainian economy afloat. While negotiating an Association Agreement and a Deep and Comprehensive Free Trade Agreement with the EU, in the framework of its eastern Partnership, Ukraine sought to reach agreement with Moscow on gas prices and energy transit fees, as well as potential participation in the Eurasian Union, including its economic component, namely the Customs Union with Russia, Belarus, and Kazakhstan. Despite an apparent incompatibility between these two economic projects, Ukraine maintained an ambiguous position up until November, when the Ukrainian president finally declined to sign the EU agreement in Vilnius. Later 
in December a 15 billion USD assistance package was agreed with Russia, including financial liquidity and lowering of energy prices. ${ }^{45}$ Again it seemed that Russia had managed to achieve its short-term goal of avoiding the deepening of Ukraine's integration into Euro-Atlantic structures. Although the cost of this operation was already high for a struggling Russian economy, the sacrifices were gradually presented to the Russian public as a fundamental part of Russia's regional and global affirmation, namely by being able to fence off Western advances into the CIS. Thus, we see that in the first stages of the crisis, there was a clear continuation of the use of traditional Russian foreign policy tools, namely the use of financial means to exert political influence, and we can also see that President Putin's leadership of the process remains mainly unchallenged. There was, however, a growing element of nationalist pressure, visible both in state propaganda against the 'West' in the Russian media, as well as in other sectors of the Russian society, which now clearly supported a vision of Ukrainian-Russian relations as being an essential part of its affirmation on a global scale. ${ }^{46}$

The popular protests that erupted in the Maidan, in downtown Kiev, in November 2013, demanding that President Yanukovych sign the Association Agreement with the EU were a clear reminder of the Orange Revolution of 2004, but still not powerful enough to provoke a revision of Ukrainian foreign policy decisions. Russian leaders continued to negotiate with the Ukrainian president, despite the popular demands for a pro-Western policy for Ukraine. The hope was clearly that President Yanukovych had re-established enough power over media and security structures to manage the demonstrations without major political consequences. Russian official statements regarding the demonstrations focused on external manipulation and the need for respect for elected officials and state institutions. ${ }^{47}$ The most important turn of events came after 21 February, when President Yanukovych fled the country to seek refuge in Russia following a round of negotiations and agreement with opposition forces. Whereas for demonstrators, opposition, and Western countries, this demonstrated that the president had relinquished his power, ${ }^{48}$ the Russian president was quite outspoken in viewing this as an illegitimate coup d'état. ${ }^{49}$ These divergent narratives were part of a strategy of disinformation and contestation, aimed at building domestic support and delegitimising Western actions in Ukraine.

Overall, this was a turning point for Russia's Ukraine strategy and a more muscular approach was set in motion, leading to the 16 March referendum in Crimea, which confirmed the desire of most Crimeans to join the Russian Federation. Despite the highly dubious conditions in which the referendum was held and despite the use of military force to seize control over the peninsula, Russia's gamble was clear. It was fundamental to prevent the new authorities in Kiev from controlling Crimea for several strategic reasons. Firstly, continued control of Crimea by the new government would create a need to negotiate the fate of the Black Sea Fleet with the new Ukrainian leaders in Kiev, implicitly 
entailing recognition of their status. Secondly, by facilitating the annexation of Crimea to the Russian Federation, President Putin gained an important card to play in both domestic and foreign politics. He managed to please Russian nationalists at home and improve his approval ratings without firing a single shot or even officially acknowledging that Russian soldiers and mercenaries had been involved in the seizing of the peninsula leading up to the March referendum. He also managed to gain a long-term pressure tool over Ukraine and Western ambitions towards it. That the decision of fully integrating Crimea into Russia was taken, rather than keeping a simmering frozen conflict of undefined political status, is explained by the historical links and perceptions in both Russia and Crimea regarding cultural, linguistic, and historical connections between the two territories. Whether this arrangement will be economically and politically viable for both parts in the future remains to be seen.

Another significant shift in the Russian strategy of using managed instability in CIS countries to assure long-term political control, is the decision to provide support for the separatist forces in the Donbas region. The humanitarian crisis, economic degradation, and political chaos facing the region today, as well as the application of sanctions by Western powers on Russia, are proving strong disappointments for the Russian population as well as for some nationalist movements in Russia. ${ }^{50}$ This demands closer attention to the interlinkages between the formulation of foreign policy choices and domestic dynamics within Russia, especially regarding the use of nationalistic discourse as a means of justifying foreign policy action. Illustrating this importance, the concept of Novorossiya comes across as particularly relevant in the current Ukrainian scenario. The concept has historically referred to the areas north of the Black Sea, which were conquered by Catherine the Great from the Ottoman Empire in the late eighteenth century, and include parts of eastern and southern Ukraine and parts of Moldova, notably Transnistria. Although it has been mostly out of use for a large part of the Soviet and Russian history, the concept has made a comeback in the context of the war in eastern Ukraine. ${ }^{51}$ As Laruelle argues, 'the concept Novorossyia does not only legitimize the insurgency; it has further implications for the Russian political landscape as it carries multiple, overlapping ideological meanings, ranging from paralleling the official narrative to calls to overthrow the Putin regime. 52

In this context, Novorossiya becomes an all-encompassing myth with varying meanings to different actors in Russia..$^{53}$ It has a variant linked to the idea of the recuperation of Soviet greatness (which is closely aligned with the Kremlin's narrative) and whose proponents (among the most salient are Alexander Dugin and Alexander Prokhanov) have been active not only in articulating the discourse sustaining Russian support for separatism in Donbas, but also on the ground, recruiting young fighters and providing material support. Another important element, which could spell important changes for Russian foreign policy and for the use of insurgency and separatist conflicts is the linking of 
Eurasianism and the 'Russian world', based among other aspects on the presence of ethnic Russians in countries of the former Soviet Union. ${ }^{54}$ A second variant of Novorossiya is infused with Orthodox views of Russian influence abroad. ${ }^{55}$ Their take on the Ukrainian crisis is one of the decadent West and Kiev authorities, against a morally superior strand of Orthodoxy in the Donbas region. This strand also adopts an imperialist and monarchist view of Russia, and they also actively recruit and send fighters to eastern Ukraine. ${ }^{56}$ Finally, the last strand identified by Laruelle sponsors a dual signification for Novorossiya: 'it announces the birth of a New Russia both geographically, in eastern Ukraine, and metaphorically, in Russia itself. ${ }^{57}$ This strand is particularly infused with neo-fascist symbols and beliefs and is divided, supporting the right-wing sector in Kiev as well as the fighters in Donbas.

Overall, it is striking that Russian foreign policy in the Ukrainian crisis has proven to be so important in domestic Russian politics. Whereas Russia's use of managed instability in the Georgian case has been a deliberate approach, well controlled from the Kremlin; it is clear that the war ravaging eastern Ukraine is far from Moscow's control - partly explaining the Kremlin's hesitations in providing explicit support to the separatists and recurring failures to reach a ceasefire and develop a crisis management approach. ${ }^{58}$ The risks of this situation are manifold. The prolonged destabilisation of Ukraine carries important economic and political costs for Russia (more so than for the EU and the United States), it prevents the normalisation of relations between Russia and its Western interlocutors, hampering the management of many important issues at the global scale, and facilitates the development of radical groups in Ukraine, Russia, but also in Western countries, emboldened by this apparent foundational shift in European geopolitics. The risks are very high for all involved.

\section{Conclusion}

The analysis of the Ukrainian crisis from the perspective of interplays between Russian domestic and foreign policies suggests important lines of continuity but also significant shifts. The article approached these processes, arguing that Russia's use of managed instability and military presence in the CIS as a means of exerting political pressure remain in place, but the current context in Ukraine poses new challenges to the Russian authorities, both in their regional and global relations, and domestically. One recurring dilemma facing Russia since the collapse of the Soviet Union is identity-building in the context of a new territorial configuration. In looking to define its national identity and its international image, Russian leaders have identified the CIS as an area of particular importance. The tools available to exert pressure on these states range from economic to military, but nevertheless the latter have remained contained within international legality, due to Russia's self-perception as a responsible global partner. The interventions in Georgia in 2008 and Ukraine in 2014 pose 
a striking change in this regard and demonstrate a reactive and more desperate foreign policy by Russia.

The combination of a nationalist narrative regarding the role of Russia outside its borders, acting as guarantor and protector of Russians abroad, and a messianic and conservative view of Russian society and its institutions has resulted in an interventionist agenda. This article has demonstrated how arguments articulated for intervention, namely in the case of Georgia and Ukraine, reflect both an incorporation of international humanitarian principles and normative arguments regarding Russia's special responsibilities towards Russians and the 'Russian world'. This combination has resulted in a Russian foreign policy that is less predictable and is creating a double identity for Russia: one where it is perceived at home as a saviour and re-established great power, and one where it is perceived abroad as an unreliable partner and imperialist power.

Thus, this foreign policy of intervention has created new challenges for Russia and its regional and global partners. Although we can argue that the costs for Russia in the case of Georgia have been limited, the stakes are far higher with respect to Ukraine. Russia has lost significant interlocutors in the West, while also raising fears within the CIS that an interventionist and imperialist policy will be pursued elsewhere, and has contributed to the long-term destabilisation of its economy and of Ukraine, one of its most valuable economic partners. Finally, another problematic trend results from the nationalist discourse sustaining Russian foreign policy and President Putin's regime, which is now actively disputed among several nationalist factions. This poses important challenges over the political future of Russia, but due to their regional views of a Russian world and due to their links to other conservative movements in the EU and in Ukraine, new forms of destabilisation may emerge, requiring cooperation between all actors involved. The conditions for this are certainly not in place, under the current situation.

\section{Notes}

1. Lo, Vladimir Putin.

2. Levada Centre, 'Approval of Putin'. Between January 2000 and December 2011, President Putin's domestic approval ratings have consistently scored above $70 \%$ and, following March 2014 (the month when Crimea was recognised as a part of the Russian Federation), his ratings recovered from an average of $65 \%$ to over $80 \%$.

3. 'Q: Is Vladimir Putin Running a Proxy War in Ukraine?'; von Eggert, 'All Politics are Local'.

4. Russian Ministry of Defence, Russian Military Doctrine.

5. Russian Federation, Foreign Policy Concept.

6. See Jackson, Russian Foreign Policy and the CIS.

7. Mitrofanova, 'The Russian World'.

8. Lo, Russian Foreign Policy, 13.

9. Sakwa, Putin, 161. 
10. Freire, A Rússia de Putin, 44. '[.. .] a construção identitária pós-Soviética acompanha a redefinição das políticas russas com Vladimir Putin, sugerindo uma "nova" Rússia construída sobre as fundações do "velho" império.'Translation by the author.

11. Allison, 'Russian Security Engagement', 86.

12. Rudensky, 'Russian Minorities', 58.

13. Putin, First Person, 133-4.

14. For an early analysis of Russia's take on Chechnya and Kosovo secessionism, see Baev, 'Russia's Stance'.

15. Trenin, 'Russia's Breakout'.

16. Freire and Simão, 'The Modernisation Agenda'.

17. Shevtsova, Putin's Russia.

18. See Nygren, 'Putin's Use of Natural Gas'; Freire, 'Russia's Energy Policies'.

19. Dunn and Bobick, 'The Empire Strikes Back'; Bobick, 'Separatism Redux'.

20. Karagiannis, 'The Russian Interventions'.

21. Kramer, 'Why Russia Intervenes'.

22. Saivetz, 'The Ties That Bind?'.

23. Putin, 'A New Integration Project'.

24. Karagiannis, 'The Russian Interventions'.

25. Torbakov, 'Russian Policymakers'.

26. From an international law perspective, Russia's military presence in Abkhazia and South Ossetia is considered to be in Georgian territory. There is a sharp difference between the peacekeeping forces stationed in these regions following the ceasefire agreements of the 1990s and the military build-up developed since 2008, based on bilateral agreements between Moscow and the separatist authorities.

27. Global Security, Russian Military Budget.

28. Baev, Russian Energy Policy, 93.

29. Dunn and Bobick, 'The Empire Strikes Back'.

30. See for instance Bukkvoll, 'Off the Cuff Politics'.

31. Ibid.

32. Nilsson, 'Russian Policy'. Felgenhauer, 'Ukraine, Russia'.

33. Nilsson, 'Russian Policy'.

34. Haran and Burkovsky, 'War in Georgia'.

35. Felgenhauer, 'Moscow Ready'.

36. Russian Federation,'The Basic Provisions'; Russian Federation, 'Conception of the Foreign Policy'.

37. Natoli, 'Weaponizing Nationality'.

38. Artman, 'Annexation by Passport'.

39. Krushelnycky, 'Fears That Crimea Could Be Next'.

40. Bukkvoll, 'Off the Cuff Politics'; Nilsson, 'Russian Policy'.

41. Saari, 'Russia's post-Orange Revolution Strategies'.

42. Bukkvoll, 'Off the Cuff Politics'; Saari,'Russia's post-Orange Revolution Strategies'.

43. Samukhvalov, 'Relations in the Russia-Ukraine-EU triangle'.

44. Krasnov and Brada,' Implicit Subsidies'.

45. 'Russia Gives Ukraine Cheap Gas'.

46. Laruelle, Russian Nationalism.

47. Marszal, 'Ukraine Protests'; 'West has "Iost sense of reality"'.

48. US Department of State. 'President Putin's Fiction'.

49. See the video of President Putin's press conference on 4 March 2014, at: https://www.youtube.com/watch?v=Hg_4D_qR18s.

50. Laruelle, 'The Ukrainian Crisis'. 
51. Hillis, Children of Rus'.

52. Laruelle,'The Three Colors of Novorossiya'. See also Jarzyńska,'Russian Nationalists'.

53. See Pribylovsky, 'Power Struggles Inside the Kremlin'.

54. Laruelle, 'The Three Colors of Novorossiya'.

55. See for instance the account by Alexander Sytnik, on the role of the Russian Institute for Strategic Research in advising the Kremlin, namely of the SVR Lieutenant General Leonid Reshetnikov and his criticism of the Kremlin's weak stance towards the former Soviet countries. Dzutsev, 'Analyst Provides Insider View'.

56. Laruelle, 'The Three Colors of Novorossiya'.

57. Ibid.

58. Freedman, 'Ukraine and the Art of Crisis Management'.

\section{Disclosure statement}

No potential conflict of interest was reported by the author.

\section{Funding}

This work was supported by European Commission [grant number 642709CASPIAN-H2020-MSCA-ITN-2014].

\section{References}

Allison, Roy. "Russian Security Engagement with the European Union." In Putin's Russia and the enlarged Europe, edited by Roy Allison, Margot Light and Stephen White, 72-93. London: Royal Institute of International Affairs, 2006.

Artman, Vincent M. 2014. 'Annexation by Passport'. Aljazeera, Opinion, March 14.

Baev, Pavel K. Russian Energy Policy and Military Power: Putin's Quest for Greatness. London: Routledge, 2008.

Baev, Pavel K. "Russia's Stance Against Secessions: from Chechnya to Kosovo." International Peacekeeping 6, no. 3 (1999): 73-94.

Bobick, Michael S. "Separatism Redux: Crimea, Transnistria, and Eurasia's De Facto States." Anthropology Today 30, no. 3 (2014): 3-8.

Bukkvoll, Tor. "Off the Cuff Politics: Explaining Russia's Lack of a Ukraine Strategy." EuropeAsia Studies 53, no. 8 (2001): 1141-1157.

Dzutsev, Valery. "Analyst Provides Insider View of Russian Government Think Tank." Eurasia Daily Monitor 12, no. 11, 20 January 2015.

Dunn, Elisabeth C. and Michael S. Bobick. "The Empire Strikes Back: War Without War and Occupation Without Occupation in the Russian Sphere of Influence." American Ethnologist - Journal of the American Ethnological Society 41, no. 3 (2014): 405-413.

Felgenhauer, Pavel. "Moscow Ready for Major Confrontations with Pro-Western Georgia and Ukraine." Eurasia Daily Monitor 5, no. 117, 19 June 2008.

Felgenhauer, Tyler. "Ukraine, Russia, and the Black Sea Fleet Accords." WWS Case Study 2 (1999).

Freedman, Lawrence. “Ukraine and the Art of Crisis Management." Survival 56, no. 3 (2014): 7-42.

Freire, Maria Raquel. A Rússia de Putin: Vectores estruturantes de política externa. [Putin's Russia: Structuring Vectors of Foreign Policy]. Coimbra: Almedina/CES, 2011. 
Freire, Maria Raquel. "Russia's Energy Policies in Eurasia: Empowerment or Entrapment?" In Russia and Its Near Neighbours: Identity, Interests and Foreign Policy, edited by Maria Raquel Freire and Roger E. Kanet, 246-264. Basingstoke: Palgrave MacMillan, 2012.

Freire, Maria Raquel and Licínia Simão. "The Modernisation Agenda in Russian Foreign Policy." European Politics and Society 16, no. 1 (2014): 126-141.

Global Security, Russian Military Budget. Accessed 2 April 2015. http://www.globalsecurity. org/military/world/russia/mo-budget.htm.

Haran, Olexiy, and Petro Burkovsky. "War in Georgia and the "Russian Card" in Ukrainian Politics." PONARS Eurasia Policy Memo 50 (December 2008).

Hillis, Faith. Children of Rus': Right-Bank Ukraine and the Invention of a Russian Nation. Ithaca, NY: Cornell University Press, 2013.

Jackson, Nicole J. Russian Foreign Policy and the CIS: Ideas, Debates and Actions in Civil and Separatist Conflicts. London: Routledge, 2003.

Jarzyńska, Katarzyna. "Russian Nationalists on the Kremlin's Policy in Ukraine." OSW Commentary, Centre for Eastern Studies, no. 156, 24 December 2014.

Karagiannis, Emmanuel. "The Russian Interventions in South Ossetia and Crimea Compared: Military Performance, Legitimacy and Goals." Contemporary Security Policy 35, no. 3 (2014): 400-420.

Kramer, Mark. "Why Russia Intervenes." Perspectives on Peace and Security, August 2014.

Krasnov, Gregory V., and Josef C. Brada. "Implicit Subsidies in Russian-Ukrainian Energy Trade." Europe-Asia Studies 49, no. 5 (1997): 825-843.

Krushelnycky, Askold. 'Fears That Crimea Could Be Next Flashpoint For Conflict With Russia'. Radio Free Europe/Radio Liberty, 24 August 2008.

Laruelle, Màrlene (ed.). Russian Nationalism. Foreign Policy and Identity Debates in Putin's Russia. Stuttgart: Ibidem Verlag, 2014.

Laruelle, Màrlene. "The Three Colors of Novorossiya, or the Russian Nationalist Mythmaking of the Ukrainian Crisis." Post-Soviet Affairs (2015): doi: http://dx.doi.org/10.1080/1060586X.2015.1023004.

Laruelle, Màrlene. "The Ukrainian Crisis and its Impact on Transforming Russian Nationalism Landscape." In Ukraine and Russia: People, Politics, Propaganda and Perspectives, edited by Agnieszka Pikulicka-Wilczewska and Richard Sakwa, 123-128. Bristol: E-IR Info, 2015.

Levada Centre. "Approval of Putin." Data available from August 1999 to November 2014 and accessed 6 January 2015. http://www.levada.ru/eng/indexes-0.

Lo, Bobo. Vladimir Putin and the Evolution of Russian Foreign Policy. London: RIIA/Blackwell Publishing, 2003.

Lo, Bobo. Russian Foreign Policy in the Post-Soviet Era: Reality, Illusion and Mythmaking. Basingstoke: Palgrave Macmillan, 2002.

Marszal. Andrew. "Ukraine Protests "More Like a Pogrom Than a Revolution”, Says Putin.” The Telegraph, 2 December 2013.

Mitrofanova, Eleonora. "The Russian World"Without Borders." Russia in Global Affairs, no. 1, January 2004.

Natoli, Kristopher. "Weaponizing Nationality: An Analysis of Russia's Passport Policy in Georgia." Boston University International Law Journal 28, no. 2 (2010): 389-417.

Nilsson, Rasmus. "Russian Policy Concerning the Black Sea Fleet and its Being Based in Ukraine, 2008-2010: Three Interpretations." Europe-Asia Studies 65, no. 6 (2013): 1154-1170.

Nygren, Birtil. “Putin's Use of Natural Gas to Reintegrate the CIS Region." Problems of PostCommunism 55, no. 4 (2008): 3-15. 
Pribylovsky, Vladimir. "Power Struggles Inside the Kremlin: A Behind-the-Scenes Look at Power Struggles Inside the Kremlin Reveals Potential Scenarios for the Future. And a Possible New President." OpenDemocracy 31 (December 2014).

Putin, Vladimir. First Person: An Astonishingly Frank Self-Portrait by Russia's President Vladimir Putin, with Nataliya Gevorkyan, Natalya Timokova, and Andrei Kolesnikov. New York, NY: PublicAffairs, 2000.

Putin, Vladimir. "A New Integration Project for Eurasia: The Future in the Making." Izvestia 3 (October 2011).

"Q: Is Vladimir Putin Running a Proxy War in Ukraine? Here is What Twelve PONARS Eurasia Experts Say." PONARS Eurasia, 24 July 2014. http://www.ponarseurasia.org/article/qvladimir-putin-running-proxy-war-ukraine-here-what-twelve-ponars-eurasia-expertssay.

Rudensky, Nikolai.'Russian Minorities in the Newly Independent States: An International Problem in the Domestic Context of Russia Today'. In National Identity and Ethnicity in Russia and the New States of Eurasia, edited by Roman Szporluk, 58-77. New York, NY: M.E. Sharp.

“Russia Gives Ukraine Cheap Gas, \$15 Billion in Loans." Kyiv Post, 17 December 2013.

Russian Federation, "The Basic Provisions of the Military Doctrine of the Russian Federation." November 1993.

Russian Federation, 'Conception of the Foreign Policy of the Russian Federation'. April 1993.

Russian Federation. Foreign Policy Concept. 2008.

Russian Ministry of Defence. Russian Military Doctrine. 2010.

Saari, Sinikukka. "Russia's post-Orange Revolution Strategies to Increase its Influence in Former Soviet Republics: Public Diplomacy po russkii." Europe-Asia Studies 66, no. 1 (2017): 50-66.

Saivetz, Carol R. "The Ties That Bind? Russia's Evolving Relations with Its Neighbors." Communist and Post-Communist Studies 45, nos. 3-4 (2012): 401-412.

Sakwa, Richard. Putin: Russia's Choice. Abingdon, UK: Routledge, 2004.

Samukhvalov, Vsevolod. "Relations in the Russia-Ukraine-EU triangle: 'Zero-Sum Game' or Not?" EU Institute for Security Studies Occasional Paper, no. 68, September 2007.

Shevtsova, Lilia. Putin's Russia, 2nd edn. Washington, DC: Carnegie Endowment for International Peace.

Torbakov, Igor. "Russian Policymakers Air Notion of "Liberal Empire" in Caucasus, Central Asia." Eurasianet 26 (October 2003).

Trenin, Dmitri. "Russia's Breakout from the Post-Cold War System: The Drivers of Putin's Course." Carnegie Moscow Centre, Paper 22 (December 2014).

US Department of State.'President Putin's Fiction: 10 False Claims about Ukraine'. 5 March 2014.

von Eggert, Konstantin. "All Politics Are Local." World Affairs, 177, no. 3 (SeptemberOctober 2014). http://www.worldaffairsjournal.org/article/all-politics-are-localcrimea-explained.

“West Has “Lost Sense of Reality” over Ukraine: Russia." Tengri News, 14 December 2013. 